\title{
The Neolithic
}

\author{
Lena Holm
}

\begin{abstract}
Publications from the time period 1986-1990 concerning the Neolithic are characterized by variation. This is seen in the different approaches and regional differences based on various archacological conditions. Studies of settlements and economic/social aspects of the societies are in majority together with an emphasis on neolithisation processes. Some studies concern theoretical approaches and methods and applications.

South Sweden, with Scania in focus, is the most well-documented region, with regional variations in the archaeological record interpreted as cultural and social differences. In central Sweden comparatively few contributions discuss problems of settlements and social and cultural structures. In Norrland, finally, differences in the archaeological record between and within coastal and inland regions are evident, signifying various Neolithic groups.
\end{abstract}

Lena Holm, Department of Archaeology, University of Umeå, S-901 87 Umeå, Sweden.

The time period 1986-1990 can be characterized as an expansive period regarding problems of the Neolithic in Sweden. This is reflected in the large amount of publications. Well over a hundred contributions are recorded in NAA (Nordic Archaeological Abstracts), both major and minor works such as monographs with doctoral theses, academic and popular papers, thematic editorial publications, and reviews and reports, some of which are multi-chronological. The greater majority of these concern the southern regions.

Problems concerning the Neolithic have principally been, and during the 1980s still are, characterized by variation. Various archaeological conditions, such as different source materials and traditions, lead archaeologists in various directions. Anyhow, one general concept that is apparent is settlement studies; here I also include economic and social aspects of the societies. Traditionally, palaeoenvironmental conditions are emphasized, and they often have a definite part in these studies. Altogether this was expressed in the concept of resource utilization, which was well used. Also in recent years more socio-cultural aspects have been included. Furthermore, problems focussing on cultural identity and the question of whether differences in the archaeological record are affiliated with different contemporaneous Neolithic groups, are discussed.

Exchange as a socio-cultural phenomenon during the Neolithic has been discussed in connection with the Battle Axe culture ("Corded Ware" culture) and also with the process of neolithisation (Strömberg 1988b; Malmer 1989; Jennbert 1988). Studies of exchange and trade during the Neolithic traditionally have their place in south and central Swedish archaeology, as represented by Welinder (1988), Larsson, M. (1988a), Hårdh (1988) and Wyszomirska (1988b).

A certain interest focussing on problems of religion and rituality can be observed. Ethnographical data constitute the base for discussions concerning primitive beliefs 
about death and the spiritual world, and are transferred to archaeological conditions (Gräslund 1989). Based on archaeological empirical materials, discussions of religious changes, votive actions, and funeral ceremonies in the Neolithic society are emphasized (Karsten 1989; Malmer 1986b; Larsson \& Larsson 1986; Larsson, L. 1988, 1989c).

In 1988 a survey of Swedish prehistory and archaeology was published with Burenhult as the main editor. The Neolithic in south and central Sweden is presented in general together with a number of problemoriented themes describing contemporary archaeological issues, and in Norrland in a survey of the prehistory of the region (Burenhult 1988).

Swedish material in particular has also been discussed by archaeologists active outside Sweden; and Swedish archaeologists have been concerned with material from outside Sweden (e.g. Bergh 1987; Knutsson et al 1990; Larsson, M. 1990; Lindqvist 1987; Persson 1987; Tilley 1989; Wyszomirska 1989).

After reading the publications it is obvious that a text of this character can be structured into some major headings: neolithisation processes, applied studies concentrated on issues of settlements and socio/ economic aspects, and studies which explicitly discuss various methods. Neolithisation processes is a subject which was introduced in the last volume of Swedish Archaeology (Jennbert 1987), and is continued here with a survey. The majority of the contributions can be characterized as applied studies, more or less theoretically approached, where empirical data constitute the base. Under the heading of methods and applications, a mixture of comparatively few publications is presented.

Some major events of the time period 1986-1990 can be mentioned, such as symposia and larger projects, now completed.

In 1988 the project 'The cultural landscape during 6000 years, a multidisciplinary study of Man and his environment in southernmost Sweden," colloquially known as "The Ystad Project" was completed. As the name indicates it was an interdisciplinary research project with long-range perspective studies. The general aim of the project was, among other things, to describe changes in the landscape and society within the Ystad area in Scania and to analyse the causes behind the changes (Berglund 1991). Several individual works on the Neolithic have been published during the time period (e.g. Larsson, L. 1987, 1989b; Larsson \& Larsson 1986). An archaeological survey was published in 1991 (Callmer et al 1991).

The research project on the Alvastra piledwelling, which started in 1976, can be seen as a continuation of earlier years excavations with the ambition to use the unique material together with modern data for studies and systematic analyses (Browall 1986). After several years of excavation the project is now completed, and the ensuing work with documentation and interpretations has resulted in several publications, including monographs (e.g. Browall 1986; During 1986; Göransson 1987a).

The Battle Axe culture has been researched and discussed for a long time. New data and problems should contribute to enlarged and changed views. Earlier discussed problems and the debate on settlement topics concerning the Nordic Battle Axe culture and other contemporaneous cultures were renewed in two symposia in Denmark and Scania (Larsson, L. 1989a). The first, held in Denmark in 1985, constituted a forum for recurrent discussions on the topic; The Settlements of Battle Axe Culture in South Scandinavia, under the heading Strids $\phi k s e$ tid $i$ Sydskandinavien (Adamsen \& Ebbesen 1986). The second, held in Lund, concerned settlements and other socio-cultural aspects (Larsson, L. 1989a).

In this context it is worth mentioning another Nordic archaeological forum, namely the second Flint Alternatives Workshop held 
in Norway in 1988 (Coulson \& Skar 1990). Archaeologists working with stone materials other than flint, among them several Swedes, have found it necessary with meetings where lectures, workshops and discussions take place. Problems concerning lithic analyses of non-flint materials, such as refitting and technical approaches to manufacture and microwear studies, are discussed and general knapping workshops are held.

Apparently the large number of publications necessitates a selection. In the following I will present a selection of the major publications on the Swedish Neolithic recorded in NAA 1986-1990. They are discussed under the headings suggested above.

\section{NEOLITHISATION PROCESSES}

The last volume of Swedish Archaeology, describing the time period 1981-1985, gave an account of the neolithisation processes in the Nordic region as a subject of their own (Jennbert 1987). Most of the recent publications concerning the Neolithic in south and central Sweden in one way or another touch upon this subject, although it is not their major aim. Here a selection of works, that exclusively treat the Neolithic and either focus on or include southern Sweden, is presented.

Neolithisation processes and the diffusion over the European continent is a subject with few contributions from Swedish archaeologists. However, it is being discussed by some (Lindqvist 1987; Persson 1987). Surveys of this kind are primarily based on earlier published material.

Concerning the neolithisation processes in south Sweden, the relationship and transition between the Mesolithic and Neolithic are in focus. At least two standpoints, based on empirical material can be discerned. The one maintains that several settlements with Ertebølle and Early Neolithic pottery in the same cultural levels indicate simultaneous use of the different pottery types and a pe- riod of gradual change from Ertebølle to Funnel Beaker culture. The other points to the obvious differences in archaeological data and settlement structures and regards them as indications of two cultures with some or no contact as well as an expansion of Funnel Beaker groups. (See e.g. Larsson, M. 1986; Jennbert 1987; Larsson L. 1987; Wyszomirska 1988a).

A summary of an earlier published dissertation by Jennbert (1984) emphasizes the slow, gradual transformation (Jennbert 1988). The approach of anthropological and palaeoecological studies improves the interpretation of the processes involved. The contact networks and exchange between Ertebølle groups in Scania and fully Neolithic groups on the Continent are interpreted as the cause of the introduction of farming and husbandry. The exchange relations brought cereals and domestic animals to the societies in south Scandinavia. Internal and external conditions made this process possible, and the fertile gift played a significant role (Jennbert 1988).

Another point of departure, seen from the Funnel Beaker perspective, is the basis of a model presented by M. Larsson (1986, 1987). Chronological differences and settlement patterns, with radical changes from Late Ertebølle on the coast to Early Neolithic in the interior, together with changes in settlement size, changes in social structure, and differences in the types of tools, are interpreted as if no contact existed between the two groups. The causes of the changes are found in the state of severe environmental pressure that the Late Ertebølle culture proved to be under. Consistent changes in settlement and social structure led to economic changes with obviously different conditions from those that existed earlier (Larsson, M. 1986).

Also a comparison of the results from some pollen diagrams in Scania and Denmark where two expansion phases are discernible, together with results from certain 
C 13 analyses, shows changes in both economy and diet. This base is laid to show significant environmental changes in the landscape. The changes are placed in relation to the local cultural-historical development in order to point to conditions that probably were of significance in the processes. Altogether this emanates from a study on comparisons between settlement structures from Late Mesolithic and Early Neolithic, where interesting factors appear to be parallel but where differences are also noticed, for example, the megalithic graves. Contacts with societies on the Continent are emphasized. On the whole, changes in social structure are accentuated as significant causes (Larsson L. 1987).

Another viewpoint, based on the idea that the transformation reflects many interacting components, is presented by Solberg (1989). Viewing Denmark, south Sweden and south Norway as a whole, archaeological data are compared with palaeoecological. The comparison, which includes Continental data, ends up in a discussion of an immigration process with an acculturation of Ertebølle groups and expansion of Funnel Beaker groups. In the complex transformations of societies, several contact networks between Scandinavia and the Continent indicate that the Scandinavian Funnel Beaker groups may have different origins (Solberg 1989).

Following the theory of gradual change, neolithisation was not only a question of the introduction of cereals and domestication of animals but also a degree of knowledge. The new species had to be treated in a special way in order to survive and multiply, to lead the Mesolithic societies to become Neolithic (Larsson L. 1987; Thomas 1988). If the concept of knowledge also comprises social aspects including ideas and magical knowledge, hypotheses could be formulated about intensified exchange and marriage systems between foragers and farmers as one cause of the processes (Thomas 1988).

Ideas and social structures are basic con- stituents of several projects of today, where causes of the transformation and subsequent processes are analysed. Comparatively many sources of material from south Scandinavia, including Scania, are part of the base when the initial and succeeding neolithisation processes in Europe are studied by Hodder (1990). As far as south Scandinavia as a whole is concerned, it is interesting to note the comparatively different interpretations of details, originally based on the same source material. Not only different theoretical approaches formulate these differences. Probably it also is a question of access to basic source material, a factor that favours those working with particular, small regions rather than with general surveys of vast areas.

Whatever the case with the problem of neolithisation, the results from the Swedish archaeological studies during the last decade reveal its complexity on Swedish grounds, with different processes occuring in various regions of Sweden (Jennbert 1987). The development may not have been uniform, but different from one region to another (Larsson, M. 1986, 1987).

Palynological studies traditionally have their place in Scandinavian archaeology. For periods they have had great impact on archaeological interpretations, particularly on the problem of neolithisation. How pollen diagrams should be interpreted, both in general and in particular, has been a subject of discussion. Following a debate among palaeobotanists, which was introduced earlier in the 1980s and which is now partly being continued, methods and results that describe the elm decline versus phases of expansion and regression in farming and chronology are high lighted (Berglund 1985; Göransson 1987b, 1989).

\section{SETTLEMENT STUDIES WITH SOCIO- ECONOMIC ASPECTS}

Swedish archaeology is characterised by long traditions of regionality. The grouping 
into regions was foremost focussed on some decades ago and is still applied. This is reflected in large numbers of distribution maps based on registered ancient monuments and stray finds. As far as the Neolithic is concerned, the megalithic graves are those monuments which are discernible in registers and manifested on distribution maps (Hyenstrand 1989).

A traditional analysis of all of Sweden's registered megaliths shows spatial differences. Based on this, a division into three regions in south Sweden is discernible. A typological approach is basic, and together with chronology as well as morphology, differences in the material are established (Blomqvist 1989).

Inevitably a certain amount of regionality will be at hand, but distribution patterning now tends to develop into economic/social approaches. Anyhow, henceforth my presentation will be divided into regions, namely, those regions which have been studied and documented during the time period 19861990 .

\section{SOUTH SWEDEN}

\section{Scania}

Regarding the Neolithic, Scania is the most well-documented province in Sweden, with extensive studies partly within larger projects. The research is characterized by settlement archaeology with emphasis on social/ economic factors in various parts of the Neolithic societies.

The majority of the archaeological record in Scania corresponds to the Danish, as part of the Neolithic south Scandinavian cultural region where archaeological problems are comparable. This is reflected in the literature, where comparisons and common culturally related phenomena are often described as a unity.

Although the province is comparatively small there are obvious differences in the material cultural remains, which imply the possibility of different local developments. The concept of regionality can also be locally applied to Scania. The extensiveness of investigations and registration implies a good base for interpretations of various approaches.

Regional variations are seen in pottery from passage-graves. A detailed analysis of elements in the decoration on Funnel Beaker pottery from Scanian passage-graves results in a division into two distinct traditions. Generality is at hand but obvious differences between the material from west Scania and that of the south and east imply a duality. In west Scania common traits and certain similar elements such as individual units indicate communication and close contacts between families or groups. The results also indicate local manufacture, probably on an individual level as well (Hårdh 1986). The usefulness of this combinations analysis is illustrated when approaching regionality in traditions between groups of families, and manufacture units in family groups as well as individuals.

Hårdh proceeds with complete or almost complete cylinder- or conus-necked vessels in a "more qualitatively directed analysis". Homogeneity, expressing common traditions with a much wider area including Denmark and north Germany, as well as individual similar traits expressing close local connections, is emphasized. In a context of intensified exchange and contacts in northern $\mathrm{Eu}$ rope, pottery manufactured in southwestern Scania constitutes part of the homogeneous group. Also, uniqueness and similarity in details indicate direct personal contact (Hårdh 1988).

Regionality is also significant in a study of settlement areas with dwellings and megaliths within southern Scania. Based on an analysis of megalithic graves, a model is discussed where regional variations in several areas - more or less continuously inhabited from the Early to the Middle Neolithic in the southern parts of the province are 
suggested as local development with permanent settlements during the Early and Middle Neolithic. In these areas settlement centres with megaliths are discerned, where locally distinguished groups of people lived as early as during phase 1 of the Early Neolithic. The megalithic graves functioned as territorial markers of segmented societies. Permanency is with few exceptions hardly demonstrated elsewhere in south Scandinavia (Larsson, M. 1988b).

As a result of several, often extensive, projects and studies our knowledge about settlements and social structures in various parts of the province has increased. In some regions proportionally few data that were known earlier have increased to such an amount that interpretations are now possible. For example, our knowledge about Early Neolithic as well as Battle-Axe settlements in southeast Scania was earlier small, but thanks to "The Ystad project" it has now increased. Settlements derived from the Mesolithic and the rest of the Neolithic have also been documented (Larsson \& Larsson 1986; Larsson, L. 1989b).

In a survey of the results, the remains from different settlements are discussed. The documentation of earlier unknown house constructions from the earliest part of the Early Neolithic, the discerning of a new local group among the earliest Neolithic settlements, and a settlement from the late BattleAxe period are among the more interesting results (Larsson \& Larsson 1986, Larsson, L. 1989b).

Studies concerning the Middle Neolithic and the Battle Axe culture in south Scania identified an increase in cultural landscape indicators such as settlements, graves and hoards distributed in the hilly as well as the coastal landscape. An obvious change from the early to the late Battle Axe culture is documented in the distribution of graves and battle-axes from the inland hilly landscape towards the coastal plain. These changes in turn are seen in connection with cultural changes that had socio/economic effects (Larsson L. 1989b). During a comparatively short time period, and in a small region, acculturation is seen with a Battle Axe culture dominance over a Funnel Beaker/Pitted Ware culture which was incorporated at the end of the Middle Neolithic (Larsson, L. $1989 \mathrm{~b}$ ). The interpretation of the results from these restricted regional studies is interesting and should have relevance beyond the region in question.

Another project, "The Hagestad project", which aims to study the use of land and other resources over a long time period, has revealed a settlement pattern similar to that described above. Strömberg discusses settlements aspects in light of the distribution and structure of settlements and graves (1989). The resources were utilized on a seasonal basis by groups belonging to larger social units, dominated by pastoralism as well as terrestrial and marine hunting and gathering (Strömberg 1988a).

Both Early and Middle Neolithic remains are represented on sites in the Nymölla area further to the north. Settlements indicate differences in economy compared with the rest of the province. The Early Neolithic Funnel Beaker community was characterized by continuity from the Late Mesolithic, and based on hunting-fishing-gathering with traditions from Mesolithic flint industry. The settlement was a centre for the manufacture of flint tools with import of flint preforms. The occupation produced both Ertebølle and Funnel-beaker pottery. The transition to agrarian production probably was delayed compared with southwestern Scania (Wyszomirska 1988a).

Against the background of the extensive investigations at Fosie, Björhem and Säfvestad discuss the Late Neolithic settlement traditions. They describe the remains of a total of twelve long-houses regarding structure, function and construction. The remains indicate dwellings divided into two parts, housing members of a mixed farming eco- 
nomy. Certain features imply a fairly permanent settlement, but indications of villages are not positive. Compared with contemporaneous settlements elsewhere, the impression of a heterogeneous house tradition during the Late Neolithic is strengthened. There are differences in comparision with the ensuing settlements of the Bronze Age, indicating changes in social structure (Björhem \& Säfvestad 1989).

\section{The Alvastra Pile-Dwelling}

I will treat the results from excavations of the Alvastra pile-dwelling in a section of their own. From the time period 1986-1990 the publications on the recent extensive excavation comprise, among others, several monographs including two doctoral theses (Browall 1986; During 1986; Göransson 1987a).

The for Swedish archaeology unique Alvastra pile-dwelling has, since it was registered in the early 20th century, been excavated and studied several times. In 1976 the latest project commenced and is now completed.

The reconstruction of the resource utilization in the Neolithic pile-dwelling community, together with an attempt to contribute to the knowledge about the Neolithic economy in the region, was the major aim of the project. The social structure-oriented approach was central for Browall, and the results are presented in his doctoral thesis (1986). Browall concludes that the site functioned as a social and ceremonial centre. New data and a survey of earlier presented results constitute the basis for his interpretation.

The abundant remains from the, in archaeological terms, extremely short occupation of the settlement, altogether 42 years, make spatial, societal and subsistence analyses possible to conduct. Based on these analyses, model calculations are discussed. The people lived foremost on agricultural products, supplemented with hunting, fishing and gathering. These activities probably took place in the surrounding resource area and the yield was then brought to the pile-dwelling (Browall 1986, 1987).

The results from the osteological analyses are well published and discussed (see Iregren in this volume). In short, the results give information on both the domestic and wild vertebrate fauna. The economy was based on cultivation, animal husbandry, and hunting as well as fishing. Among the identified species, the domesticated cattle are most frequent; age and sex data also indicate that they were kept for reproductive purposes (During 1986).

Dendrochronological and wood anatomical investigations together with pollen analyses contribute to the reconstruction of the pile-dwelling and its environmental surroundings (Bartholin 1987; Göransson 1987a). A combination of dendrochronological datings makes a reconstruction of activity phases in the pile-dwelling possible (Bartholin 1987). The prehistoric forest landscape around the Alvastra pile-dwelling has been reconstructed through a series of pollen diagrams. The results suggest that a permanent settlement was established with a rotation system for cereal cultivation in a landscape that was almost totally influenced by man (Göransson 1987a).

\section{Gotland}

The settlement pattern, economy and social structure on Gotland during the Stone Age have been analysed by Österholm (1989). In her doctoral thesis, Österholm comprises data from previous investigations and new material, with certain emphasis on pottery analysis. The study is "typical" in the sense that the results are based on both archaeological, palynological, and various prospecting methods.

The results point towards a pattern with 13 separate coastal-bound settlement areas and one in the centre of the island. The sites were strategically localised with access to several ecological zones in sheltered areas 
and on well-drained soils. Continuity is central with some exceptions; an interruption is noticed in the Early Neolithic. During that time the inner parts of the resource areas were cleared and cultivated. In the Middle Neolithic there was a gradual moving back to coastal areas. This is the time when the large Pitted Ware sites become visible. The changes are visible in, among others, the Ajvide site. Different analyses, e.g. on Pitted Ware pottery, indicate economic and technical changes as well as changes on pottery (Österholm 1989).

\section{CENTRAL SWEDEN}

The archaeological picture of central Sweden is complex. Although much has been done, there are several gaps to be filled, both empirically and with respect to archaeological problems. There are still regions where much basic research is needed. Here, central Sweden constitutes an undefined part of Sweden between the south and the north.

Variations in the landscape in central Sweden imply different conditions for human activities during the Stone Age. With these factors as a base, a survey of hitherto conducted Stone Age research is made with an emphasis on the last twenty years. As far as the Neolithic is concerned, several of the excavations refer to remains from the Middle Neolithic Pitted Ware culture (Olsson \& Åkerlund 1987).

As mentioned earlier, there are several gaps to fill and regions where much work remains. The northern part of central Sweden is such a region. Beyond specific problems it is obvious that basic research is necessary. These conditions offer good possibilities for solving a variety of problems.

The northern part is a so-called "middle area" or a southern hunting-gathering area. Based on the distribution patterns of different implements, the region is seen as a "frontier" between the northern hunter-gatherers and the southern Neolithic cultures (Hyenstrand 1987).
In the research concerning the Neolithic much attention was earlier given to chronology. The problem of the relation between a hunting-gathering and an agrarian economy, characterized by Pitted Ware and Funnel Beaker pottery on the one hand and the latter on the other, is complex and needs new approaches. Welinder, in a study of ceramic styles from a site with both traditions present, argues for an independent chronology for the central Swedish Stone Age pottery. The observed changes in pottery style at the site do not necessarily correspond to an apparent economic change (Welinder 1987).

Empirical studies present data that contribute to the collected archaeological research status by filling in the gaps. A recent excavation with remains from three houses, together with a fire-cracked mould and a stone cist, points to a closed Late Neolithic environment with possibilities for discussions of the subsistence and population. Additionally, technical aspects such as house construction are possible subjects to elucidate. The stone cist is one among few to be excavated in this part of Sweden (Andersson \& Hjärtner-Holdar 1989). Altogether these aspects are of importance in the discussions of the central Swedish Late Neolithic and the transition to the Bronze Age.

\section{NORTH SWEDEN (NORRLAND)}

Norrland should by no means be regarded as one uniform region in terms of geography, ecology or even economy/society. There are obvious differences in all respects. Nevertheless, it is apprehended as one region in a cultural historical sense. Archaeologically we can take the south, central and north Norrland with the coastal region and interior into account.

The publications from the time period 1986-1990 can be divided into surveys and studies of long-term character which either include the Neolithic or are clearly defined as Neolithic. This is due to the state of research and the conditions of the archaeo- 
logical record, respectively; today there are adequate data, even though not sufficient from all parts, which enable the writing of surveys and ease the apparent difficulties in "pressing" data into a chronology constructed for other (non-identical) conditions.

\section{Surveys of prehistoric Norrland}

During the Neolithic the picture is complex, with various regional traditions or groups reflected in the archaeological record, for example, in the ceramics and raw material. Baudou argues for a north Scandinavian independent development of the artefacts (1989b).

In his survey of north Swedish prehistory Baudou discusses the spread of agriculture based on palynological and archaeological data. The earliest indications of farming, which are seen as sporadic events, date to the Middle Neolithic. These indications together with implements of south Scandinavian origin found on settlements and in hoards are seen as features linked to immigrating groups of people who have their origin to the south of Dalälven River. This is foremost a coastal phenomenon with different types of implements compared with other parts of Norrland (1989b).

Although the economy is similar during the entire prehistory in the interior of Norrland, there are significant changes in technique and settlement patterns. Concerning the Neolithic, this is foremost evident in the later part of the period. During the Late Neolithic and the transition to the Bronze Age changes in the flaking technique of stone materials are evident. Furthermore, changes in settlement patterns and subsistence and the introduction of asbestos ceramics are interpreted as a total social reorganisation (Forsberg 1989).

\section{Coastal areas}

Flint as an exotic rock material in northern Sweden and finds of flint in assemblages as well as stray finds and hoards have had great emphasis for a long time. Recently Becker re-emphasized this issue by pointing to the problems connected, among other things, with the classification and determination of the sources of the originally south Scandinavian implements (1988).

The north Swedish archaeological record of the Neolithic signifies various cultural groups, mostly accentuated in the coastal areas. Several studies emphasize problems concentrated on this issue. For example, finds of battle-axes and Battle Axe pottery along the Bothnian coast have been interpreted as indicating south Scandinavian groups of people immigrating to Norrland. The connections from south to north are continously seen along the coast, up to the Bronze Age. The occurence of remains of the Battle Axe culture is not seen as an occasional phenomenon but as part of the earlier mentioned continuity (Baudou 1989a).

Site material, hoards and stray finds of the Middle Neolithic are the most marked Neolithic finds in Norrland. These categories of material are foremost found along the Bothnian coast but also in the interior of Norrland. Flint is significant in this context. In Västerbotten several Neolithic sites were excavated in the Nordarkeologi project (Christiansson \& Knutsson 1989).

Whether the flint on these sites is the result of internal development, diffusion or migration is the main topic of the study. With experimental simulations, technical analyses, and refitting of flint in assemblages from Middle Neolithic sites in Västerbotten as a base, Knutsson in his doctoral thesis discusses problems of settlements and flaking strategies. The results lead to a discussion of the introduction of flint into Västerbotten. In the Middle Neolithic a sequence with local quartz-using groups is seen. In the transition to the Late Neolithic, flint flaking is practised by immigrants from southernmost Scandinavia. Later, the bifacial and quartz techniques indicate local use (Knutsson 1988). 
Seen in their context, settlements, hoards and lithic technological strategies together point towards an interpretation of migration by south Scandinavians to Norrland in the end of the Middle Neolithic. However, this did not result in significant local changes in subsistence or technological strategies (Knutsson 1988).

\section{The interior}

The radical changes during the Late Neolithic that are reflected in the archaeological record can be studied in more detail, for example, concerning the use of stone materials. In a study of interior conditions, characterized by analyses of stone assemblages from all time periods B. C., significant changes are seen in the use of stone and flaking techniques. These changes are interpreted as a more intensified and specialized use of stone material from the Late Neolithic and onwards (Holm 1989).

So-called fire-cracked stone mounds are characteristic of the interior of central and northern Norrland. During the time period 1986-1990 they have been discussed from various angles by several archaeologists (for example Lundberg 1986; Spång 1986).

The constructions with fire-cracked stones are interpreted as the remains of huts. They are found in groups in a distinctive settlement pattern in the interior, interpreted as more sedentary winter base-camps (Lundberg 1986).

The micro-environmental conditions thanks to several investigations are considerably well established by now. Together with their local settlement pattern, closely connected with pitfalls, these circumstances favour an analysis of the Neolithic subsistence and social structure in the interior of Norrland.

\section{THEORY, METHODS AND}

\section{APPLICATIONS}

Although Swedish archaeology traditionally can be seen as foremost empirical, with com- parably little room for theory, there is an ever growing interest in theory. Archaeological methods are more evolved and more or less explicitly used in most publications. There is an increasing development in the field. Here a selection of contributions that discuss methods more explicitly are presented.

Ethnoarchaeological aspects have been discussed and applied to some Swedish material during the 1980s; for example, Burenhult used ethnographical analogies as a method in his editorial work (1988).

Also the concept of ethnoarchaeology is discussed by Malmer; among other things, he questions the definitions and the exclusiveness of the concept. Concerning the Battle Axe culture, analogies are applied to types such as battle-axes and pottery in the context of utilitarian, trade and symbolic factors (Malmer 1989).

Continuing with the Battle Axe culture, the report from the first symposium in south Scandinavia is introduced with a theoretical reflection upon chronology and social aspects. Arguments for the hypothetical-deductive method are proposed as an answer in the still ongoing debate on the method. The representativity of sources and the structuring of the results earlier presented by Malmer have been questioned ever since, including the beginning of the 1980s (Malmer 1986a).

In a work on megaliths, social aspects such as kinship and labour are emphasized (Sjögren 1986). With a description of the theoretical structure of a social archaeology as the base, social models such as "lineage" and "Big man" societies are discussed with a materialistic approach. By comparing tomb features in megalithic graves in southwestern Sweden with this explicit materialistic approach, which includes an ethnoarchaeological perspective, Sjögren tests different assumptions. Although several of them were not possible to test, he concludes that interesting structural differences exist between 
the Bohuslän and Västergötland regions (1986). Even though the result was not positive in the way we usually expect, Sjögren in his study makes a noteworthy attempt to link theory with empirical data.

The investigations and results of "The Hagestad project" have provided good opportunities for applying source-critical methods regarding preservation conditions and the problem of representativeness of settlement remains and graves to areas with intensive agricultural activities (Strömberg 1987). Also the results from "The Ystad Project" are taken as a base for a more theoretical discussion, exemplified foremost by scientific results from and concerning the neolithisation process in Scania (see above) (Larsson, L. 1987).

Prospecting methods have foremost been used to find later material such as Bronze and Iron Age settlements. Various methods such as aerial photography, phosphate surveys, as well as pollen analyses, supplemental to archaeological methods in the search for Stone Age sites, have been practised on Gotland. The methods have improved the efficiency of field-work and revealed differences in settlement pattern (Österholm 1987).

Noteworthy in this context are the earlier mentioned results of combinations analysis on megalithic pottery decoration, which indicate regional variations, implying a duality, at the same time as there are observable general traits (Hårdh 1986). In another study, which is a continuation, Hårdh concentrates on methods of deposition and regional chronology in west Scania (1990). Based on the explicit use of combinations analysis, the techniques of pottery decoration show chronological differences. Widened with a combinations analysis on depositions in tombs, the study leads to a hypothesis about the pattern of deposition in the region (Hårdh 1990).

One problem which is not quite theoretical in character but tangent to, and which has received a fair amount of attention, is whether the Neolithic groups (that is, the Funnel Beaker, Battle Axe and Pitted Ware cultures) should be seen as several separate cultures, as influencing each other, as reflecting various aspects of the same culture, or, as L. Larsson argues, as an acculturation among them later in the Neolithic period (1986). The localization of Battle Axe sites gives new knowledge to this discussion. Based on material from various parts of Sweden, this topic has been discussed by several archaeologists who approach it from various theoretical standpoints (for example Persson 1986; Larsson, L. 1986, 1989b; Strömberg 1989; Carlsson 1987; Tilley 1989).

\section{CONCLUDING REMARKS}

Problems of the Neolithic in Swedish archaeology can be characterized as a variety of approaches, partly due to different conditions (e.g. source materials and traditions). One general concept that is discernible is settlement studies, which also includes economic and social aspects of the societies. Also, palaeoecological studies traditionally have been emphasized within Nordic archaeology and still are during the 1980s. Discussions with explicit emphasis on neolithisation processes in the southern regions take their base in these conclusions.

Analyses of settlement features and settlement patterns, economic and social structures, and palaeoenvironmental conditions were the bases of several interpretations concerning various aspects of the Neolithic societies, altogether often explained in terms of resource utilization. Additionally, socio-cultural aspects are included in several studies which focus, among other things, on cultural distinctive features and identities along with problems of religious aspects.

I want to conclude my selective survey of the archaeology of the Neolithic in the time period 1986-1990 with some reflections on the years to come.

I may have described Swedish archaeo- 
logy as traditionally rooted in empiricism and bound to tradition. This should be apprehended in a positive sense with positive meanings. The tradition of, for example, settlement studies with aspects of economic and social structures will continue, as will the environmental archaeology.

Ethnoarchaeological approaches probably will be developed. And theoretical aspects will certainly be discussed and improved. With these factors as a base we have seen an initial change, partly described earlier, which is influenced by the ongoing theoretical debate and which probably will

\section{REFERENCES}

Adamsen, Ch. \& Ebbesen, K. (Eds.) 1986. Strids$\emptyset k$ setid i Sydskandinavien. Beretning fra et symposium 28-30.X. 1985 i Vejle. Arkæologiske Skrifter 1. København.

Andersson, K. \& Hjärtner-Holdar, E. 1989. Annelund - ett senneolitiskt bebyggelsekomplex i sydvästra Uppland. Fornvännen:209-215.

Bartholin, Th. 1987. "Oak and Willow": Active and Passive periods at Alvastra Pile Dwelling. A Result of Dendrochronological and Wood Anatomical Investigations. In: Burenhult, G., Carlsson, A., Hyenstrand, A. \& Sjøvold, T. (Eds) 1987. Theoretical Approaches to Artefacts, Settlement and Society. Studies in honour of Mats P. Malmer. B A R International Series 366:123-132. Oxford.

Baudou, E. 1989a. Finns stridsyxekultur i Norrland? In: Larsson, L. (Ed). Stridsyxekultur $i$ Sydskandinavien. Rapport från det andra nordiska symposiet om Stridsyxetid i Sydskandinavien. University of Lund. Institute of Archaeology Report Series No 36:103-109.

$-1989 \mathrm{~b}$. Stability and Long Term Changes in North Swedish Prehistory: An Example of CentrePheriphery Relations. In: Larsson, T. B. \& Lundmark, H. (eds.) Approaches to Swedish Prehistory. A spectrum of problems and perspectives in contemporary research. B A R International Series 500:27-53. Oxford.

Becker, C. J. 1988. Sydskandinavisk flint i nordsvenske fund fra mellem- og senneolitisk tid. Iskos 7:43-53. improve; emphasis is laid on cultural and social aspects.

Regarding neolithisation processes the discussions will probably focus more on social aspects, and they may lead to a concept where the processes are seen as phenomena rather than reconstructions. Concerning societal and settlement studies the focus will probably change from economic aspects to a concept which more explicitly stresses cultural traits.

English revised by Laura Wrang.

Bergh, S. 1987. Court Tombs, Passage Tombs and Social Contexts in North County Sligo, Ireland. In: Burenhult, G., Carlsson, A., Hyenstrand, Å.\& Sjøvold,T. (Eds) 1987. Theoretical Approaches to Artefacts, Settlement and Society. Studies in honour of Mats P. Malmer. B A R International Series 366:241-255. Oxford.

Berglund, B. E. 1985. Early Agriculture in Scandinavia: Research Problems related to Pollenanalytical Studies. Norw. Arch. Rev. vol 18, nos 1-2:77-105.

-1991. The project - background, aims, and organization. In: Berglund, B.E. (Ed.). The cultural landscape during 6000 years in southern Sweden - the Ystad project. Ecol. Bull. 41:13-17.

Björhem, N. \& Säfvestad, U. 1989. Fosie IV. Byggnadstradition och bosättningsmönster under senneolitikum. Malmöfynd 5.

Blomqvist, L. 1989. Megalitgravarna i Sverige. Typ, tid, rum och social miljö. Theses and Papers in Archaeology 1. Stockholm.

Browall, H. 1986. Alvastra pålbyggnad: social och ekonomisk bas. Theses and papers in North-European Archaeology 15. Stockholm. -1987. The Alvastra Pile Dwelling: Its Social and Economic Basis. In: Burenhult, G., Carlsson, A., Hyenstrand, Å. \& Sjøvold, T. (Eds) 1987. Theoretical Approaches to Artefacts, Settlement and Society. Studies in honour of Mats P. Malmer. B A R International Series 366:95121. Oxford. 
Burenhult, G. 1988. (Ed.) Länkar till vår forntid en introduktion i Sveriges arkeologi.

Callmer, J., Larsson, L. \& Stjernquist, B. (Eds.) 1991. The Archaeology of the Cultural Landscape. Acta Archaeologica Lundensia. Series $4^{\circ}$. Lund.

Carlsson, A. 1987. Three Stone Age Cultures in the Province of Södermanland, Eastern Central Sweden - Fact or Fiction? In: Burenhult, G., Carlsson, A., Hyenstrand, A. \& Sjøvold, T. (Eds) 1987. Theoretical Approaches to Artefacts, Settlement and Society. Studies in honour of Mats P. Malmer. B A R International Series 366:231-239. Oxford.

Christiansson, H. \& Knutsson, K. (Eds). 1989. The Bjurselet Settlement III. Vol I\&2. Occasional Papers in Archaeology 1. Societas Archaeologica Upsaliensis. Uppsala.

Coulson, S. \& Skar, B. 1990. The Second Flint Alternatives Workshop. Universitetets Oldsaksamling Arbok 1989/1990:71.

During, E. 1986. The Fauna of Alvastra. An Osteological Analysis of Animal Bones from a Neolithic Pile Dwelling. Ossa 12, Supplement 1. Stockholm.

Forsberg, L. 1989. Economic and Social Change in the Interior of Northern Sweden 6000 B.C. 1000 A.D. In: Larsson, T. B. \& Lundmark, H. (Eds.). Approaches to Swedish Prehistory. A spectrum of problems and perspectives in contemporary research. B A R International Series 500:55-82. Oxford.

Gräslund, B. 1989. Gånggrifternas funktion i ljuset av primitiv själstro. In: Larsson, L. \& Wyszomirska, B. (Eds). Arkeologi och religion. Rapport från arkeologidagarna 16-18 januari 1989. University of Lund. Institute of Archaeology Report Series No 34:67-76.

Göransson, H. 1987a. Neolithic Man and The Forest Environment around Alvastra Pile Dwelling. Theses and Papers in North-European Archaeology 20. Stockholm.

-1987b. On Arguing in a Circle, on Common Sense, on the Smashing of Paradigms, on Thistles among Flowers, and on Other Things. Norw. Arch Rev. Vol 20 No 1:43-45.

-1989. Konstanter och variabler i det förhistoriska samhället - en kommentar. Fornvännen 84:4347.

Hodder, I. 1990. The Domestication of Europe. Structure and Contingency in Neolithic Societies. Oxford.
Holm, L. 1989. Manufacture of Stone Tools in Northern Sweden - A Study of Stone Assemblages in the Caledonian Chain. In: Larsson, T. B. \& Lundmark, H. (Eds.). Approaches to Swedish Prehistory. A spectrum of problems and perspectives in contemporary research. B A $\mathrm{R}$ International Series 500:191-210. Oxford.

Hyenstrand, Å. 1987. Stone Age Frontiers - An Example from Middle Sweden. In: Burenhult, G., Carlsson, A., Hyenstrand, Å. \& Sjøvold, T. (Eds) 1987. Theoretical Approaches to Artefacts, Settlement and Society. Studies in honour of Mats P. Malmer. B A R International Series 366:209-230. Oxford.

-1989. Southern Sweden: An Archaeological Field of Research. In. Larsson, Th. B. \& Lundmark, H. (Eds). Approaches to Swedish Prehistory. A spectrum of problems and perspectives in contemporary research. B A R International series 500:99-104. Oxford.

Hårdh, B. 1986. Ceramic Decoration and Social Organization. Regional variations seen in material from south Swedish passage-graves. Scripta Minora. Studier utgivna av Kungl. Humanistiska Vetenskapssamfundet i Lund 1985-1986:1. Lund.

-1988. Coastal Connections in the Scanian Middle Neolithic. In: Hårdh, B. et al. (Eds). Trade and Exchange in Prehistory. Studies in Honour of Berta Stjernquist. Acta Archaeologica Lundensia Series in $8^{\circ}$ No 16:59-70. Lund.

-1990. Patterns of Deposition and Settlement. Studies on the megalithic tombs of west Scania. Scripta Minora. Studier utgivna av Kungl. Humanistiska vetenskapssamfundet i Lund 1988-1989:2. Lund.

Jennbert, K. 1984. Den produktiva gåvan. Tradition och innovation i Sydskandinavien för omkring 5300 år sedan. Acta Archaeologica Lundensia Ser. prima in $4^{\circ}$ No 16.

-1987. Neolithisation Processes in the Nordic Area. Swedish Archaeology 1981-1985:21-35. Svenska Arkeologiska Samfundet. Stockholm.

-1988. Der Neolithisierungsprozeß in Südskandinavien. Prahistorische Zeitschrift 63. Band heft 1:1-22.

Karsten, P. 1989. Rituella neolitiska fynd i Skåne. In: Larsson, L. \& Wyszomirska, B. (Eds). Arkeologi och religion. Rapport frain arkeologidagarna 16-18 januari 1989. University of Lund. Institute of Archaeology Report Series 
No 34:77-86.

Knutsson, K. 1988. Making and using stone tools.

The analysis of the lithic assemblages from the Middle Neolithic sites with flint in Västerbotten, northern Sweden. Aun 11. Uppsala.

Knutsson, K., Welinder, S. \& Uleberg, E. 1990. One fine day in the Norwegian high mountains. UOÅrbok 1989-1990:61-69.

Larsson, L. 1986. Skåne under sen trattbägarkultur. In: Adamsen, Ch. \& Ebbesen, K. (Eds). Strids $\phi k s e t i d i$ Sydskandinavien. Beretning fra et symposium 28.-30.X. 1985 i Vejle. Arkæologiske Skrifter 1: 146-155. København.

-1987. Some Aspects of Cultural Relationship and Ecological Conditions During the Late Mesolithic and Early Neolithic. In: Burenhult, G., Carlsson, A., Hyenstrand, А. \& Sjøvold, T. (Eds) 1987. Theoretical Approaches to Artefacts, Settlement and Society. Studies in honour of Mats P. Malmer. B A R International Series 366:165-176. Oxford.

-1988. Mortuary Building above Stone Age Grave.

A grave from the Battle Axe Culture at Ullstorp, Southern Scania, Sweden. MeddLUHM 1987-1988. Papers of the Archaeological Institute University of Lund 1987-1988 New series Vol 7:81-98.

-1989a. (Ed.) Stridsyxekultur i Sydskandinavien. Rapport frän det andra nordiska symposiet om Stridsyxetid $i$ Sydskandinavien 31.X - 2.XI 1988. University of Lund. Institute of Archaeology Report Series No 36.

-1989 b. Boplatser, bebyggelse och bygder. Stridsyxekultur i södra Skåne. In: Larsson, L. (Ed). Stridsyxekultur i Sydskandinavien. Rapport från det andra nordiska symposiet om Stridsyxetid i Sydskandinavien 31. X - 2. XI 1988. University of Lund. Institute of Archaeology Report Series No. 36:53-87.

-1989c. Brännoffer. En tidigneolitisk fyndplats med brända flintyxor från södra Skåne. In: Larsson, L. \& Wyszomirska, B. (Eds). Arkeologi och religion. Rapport frän arkeologidagarna 16-18 januari 1989. University of Lund. Institute of Archaeology Report Series No 34:87-97.

Larsson, L. \& Larsson, M. 1986. Stenåldersbebyggelse i Ystadområdet. En presentation av fältverksamhet och bearbetning hösten 1984 våren 1986. Ystadiana 1986:9-78.

Larsson, M. 1986. Neolithization in Scania - A Funnel Beaker Perspective. Journal of Danish
Archaeology vol 5:244-247.

-1987. From Hunters to Farmers. The evolution of the Early Neolithic TRB culture in Scania, Sweden. In: Wislanski, T. (Ed.) Neolit i poczatki epoki brazu na ziemi chelminskiej. Torun 1987:323-348.

-1988a. Exchange and Society in the Early Neolithic in Scania, Sweden. In: Hårdh, B. et al. (Eds). Trade and Exchange in Prehistory. Studies in Honour of Berta Stjernquist. Acta Archaeologica Lundensia Series in $8^{\circ}$ No 16 : 49-58. Lund.

$-1988 \mathrm{~b}$. Megaliths and Society. The development of Social Territories in the South Scanian Funnel Beaker Culture. MeddLUHM 1987-1988. Papers of the Archaeological Institute University of Lund 1987-1988. New Series Vol 7: 19 39.

-1990. Einhegungen in der südskandinavischen Trichterbecherkultur. Gesellschaftlicher und wirtschaftlicher Hintergrund. Jahresschrift für mitteldeutsche Vorgeschichte band 73, 1990: 441-447.

Lindqvist, Ch. 1987. Analogies in the Spread of Neolithic and Later Innovations over Europe and Africa. In: Burenhult, G., Carlsson, A., Hyenstrand, $\AA . \&$ Sjøvold, T. (Eds) 1987. Theoretical Approaches to Artefacts, Settlement and Society. Studies in honour of Mats P. Malmer. B A R International Series 366:177-197. Oxford.

Lundberg, Å. 1986. Skärvstensvallar i Norrland. In: Studier i norrländsk forntid II. Acta Bothniensia Occidentalis. Skrifter i västerbottnisk kulturhistoria 8:81-99.

Malmer, M. P. 1986a. Vad kan vetas om stridsyxekulturens kronologiska och sociala förhållanden? Teoretiska betraktelser. In: Adamsen, Ch. \& Ebbesen, K. (Eds) Strid $\phi k s e t i d$ i Sydskandinavien. Beretning fra et symposium 28.30.X. 1985 i Vejle. Arkæologiske Skrifter 1:721. København.

-1986b. Aspects of Neolithic Ritual Sites. In: Steinsland, G. (Ed.) Words and Objects. Institutt for sammenlignende kulturforskning 1986 : 91-110. Oslo.

-1989. Etnoarkeologiska synpunkter på stridsyxekulturen. In: Larsson, L. (Ed). Stridsyxekultur i Sydskandinavien. Rapport från det andra nordiska symposiet om Stridsyxetid $i$ Sydskandinavien 31. X - 2. XI 1988. University of Lund. Institute of Archaeology Report Series 
No 36: 7-12.

Olsson, E. \& Åkerlund, A. 1987. Stenåldersundersökningar i östra mellansverige. 7000 år på 20 år 1987:9-40. Stockholm.

Persson, P. 1986. Några kommentarer till en lista över STY boplatsfynd från den svenska västkusten. In: Adamsen, Ch. \& Ebbesen, K. (Eds). Strids $\emptyset$ ksetid i Sydskandinavien. Beretning fra et symposium 28.-30. X. 1985 i Vejle. Arkæologiske Skrifter 1: 166-275. København.

-1987. Etapper i lantbrukets spridning. En rekonstruktion utifrain de tidigaste spåren $i$ nordvästeuropa. GOTARC Serie C. Arkeologiska skrifter No 4. Göteborg.

Sjögren, K-G. 1986. Kinship, Labor and Land in Neolithic Southwest Sweden: Social Aspects of Megalithic Graves. Journal of Anthropological Archaeology 5:229-265.

Solberg, B. 1989. The Neolithic Transition in Southern Scandinavia: Internal Development or Migration? Oxford Journal of Archaeology 5:229-265.

Spång, L-G. 1986. Stenåldersbostaden. In: Studier $i$ norrländsk forntid $I I$. Acta Bothniensia Occidentalis. Skrifter i västerbottnisk kulturhistoria 8:47-80. Umeå.

Strömberg, M. 1987. Factors of Importance for Interpreting Settlement Patterns. In: Burenhult, G., Carlsson, A., Hyenstrand, Å. \& Sjøvold, T. (Eds). Theoretical Approaches to Artefacts, Settlement and Society. Studies in honour of Mats P. Malmer. B A R International Series 366: 43-52. Oxford.

-1988a. A Complex Hunting and Production Area. Problems associated with a Group of Neolithic Sites to the South of Hagestad. Medd LUHM 1987-1988. Papers of the Archaeological Institute University of Lund 1987-1988. New series Vol 7:54-80.

-1988b. Exchange Systems between Battle-Axe Groups? Some reflections concerning certain finds from South-East Scania. In: Hårdh, B. et al (Eds.). Trade and Exchange in Prehistory. Studies in honour of Berta Stjernquist. Acta Archaeologica Lundensia Series in $8^{\circ}$. No 16: 71-81. Lund.

-1989. Stridsyxekulturens representation i Hagestadsprojektets arbetsområde. In: Larsson, L. (Ed). Stridsyxekultur i Sydskandinavien. Rapport från det andra nordiska symposiet om Stridsyxetid i Sydskandinavien 31.X - 2. XI 1988. University of Lund. Institute of Arch- aeology Report Series No 36:77-87.

Thomas, J. 1988. Neolithic Explanations Revisited: The Mesolithic-neolithic Transition in Britain and South Scandinavia. Proceedings of the Prehistoric Society 54:59-66.

Tilley, Ch. 1989. Hunter-Gatherers, Farmers and the Social Structuring of Material Culture. In: Larsson, Th. B. \& Lundmark, H. (Eds). Approaches to Swedish Prehistory. A spectrum of problems and perspectives in contemporary research. B A R International Series 500:239285. Oxford.

Welinder, S. 1987. Keramikstilar på Fågelbacken för 5000 år sedan. Västmanlands fornminnesförening och Västmanlands läns museum Ärsskrift 65: 101-120.

-1988. Exchange of Axes in the Early Neolithic Farming Society of Middle Sweden. In: Hårdh, B. et al. (Eds). Trade and Exchange in Prehistory. Studies in Honour of Berta Stjernquist. Acta Archaeologica Lundensia Series in $8^{\circ}$ No 16:41-48.

Wyszomirska, B. 1988a. Ekonomisk stabilitet vid kusten. Nymölla III. En tidigneolitisk bosättning med fångstekonomi $i$ nordöstra Skåne. Acta Archaeologica Lundensia Series in $8^{\circ} \mathrm{Nr}$ 17. Lund.

$-1988 \mathrm{~b}$. Flint production and Flint trade in Northeastern Scania. In: Hårdh, B. et al. (Eds). Trade and Exchange in Prehistory. Studies in Honour of Berta Stjernquist. Acta Archaeologica Lundensia Series in $8^{\circ}$ No 16:83-98. Lund.

-1989. Rzucewo kultur vid den södra Östersjökusten. Den snörkeramiska traditionens periferi? In: Larsson, L.(Ed). Stridsyxekultur i Sydskandinavien. Rapport från det andra nordiska symposiet om Stridsyxetid i Sydskandinavien 31. X - 2. XI 1988. University of Lund. Institute of Archaeology Report Series No 36: 181194.

Österholm, I. 1987. Search for Stone Age Settlements on Gotland. In: Burenhult, G., Carlsson, A., Hyenstrand, A. \& Sjøvold, T. (Eds). Theoretical Approaches to Artefacts, Settlement and Society. Studies in honour of Mats P. Malmer. B A R International Series 366: 199-208. Oxford.

-1989. Bosättningsmönstret på Gotland under stenåldern. En analys av fysisk miljö, ekonomi och social struktur: Theses and Papers in Archaeology 3. Stockholm. 
